\title{
THE RELATIONSHIP OF PREGNAN WOMEN'S CHARACTERISTICS TO THEIR PERCEPTION OF THE MCH BOOK, BENDA KEREP UB-VILLAGE, ARGASUNYA VILLAGE, CIREBON CITY
}

\author{
Vianty Mutya Sari $^{1^{*}}$, Nurhasanah ${ }^{2}$ \\ ${ }^{I}$ STIKes Muhammadiyah Cirebon, Cirebon, dan Kode Pos 45143, Indonesia \\ ${ }^{2}$ STIKes Muhammadiyah Cirebon, Cirebon, dan Kode Pos 45143, Indonesia
}

\section{INFORMASI ARTIKEL:}

\section{Riwayat Artikel:}

Tanggal diterima: Maret 2021

Tanggal di revisi: Maret 2021

Tanggal di Publikasi: April 2021

Keywords: characteristics, perception, MCH book, pregnant women

\section{A B S T R A C T}

In Indonesia, breast cancer is the second leading cause of death for women after cervical cancer. Based on data from the Cirebon City Health Office in 2015, the number of maternal deaths was 4/5400 live births, the number of infant deaths was $25 / 5455$ live births, and the number of under-five deaths was 8/5378 live births. Aspects of maternal and child health can be seen from several indicators of achievement, one of which is Infant Immunization. In 2015, of 22 urban villages in the city of Cirebon, there was only one village that had not reached the target, namely in the Argasunya village. Meanwhile, the coverage of deliveries by health workers in Argasunya was 52.64\% and the highest delivery assistance by traditional birth attendants in the city of cirebon was in Argasunya Village at $4.63 \%$. The purpose of this study was to determine the relationship between characteristics and perceptions of pregnant women on the MCH Handbook. This study used a cross sectional design. The population of all pregnant women in Benda Kerep SubVillage, Argasunya Village, Cirebon City. Sampling used total sampling. The data taken were primary data obtained through questionnaires given to 23 pregnant women. The correlation test used Chi-Square. The results of the study showed that the majority of pregnant women had a bad perception of the MCH handbook $(69.56 \%)$, were aged $20-35(87 \%)$, graduated from elementary school $(78 \%)$, were with 14-27 weeks in gestation (48\%), and had a plan to deliver at home (73.92\%). Based on occupation, all pregnant women did not work (100\%). There was no relationship between age and perception of the $\mathrm{MCH}$ handbook, between education and perception of the MCH handbook, between occupation and perception of the $\mathrm{MCH}$ handbook, and between planned place of delivery and perception of the $\mathrm{MCH}$ handbook.. 


\section{INTRODUCTION}

Maternal death can occur during pregnancy, during childbirth and during the puerperium caused by lack of knowledge to recognize danger signs experienced such as excessive nausea and vomiting, bleeding, premature rupture of membranes, fever, swelling of the hands and even face accompanied by blood pressure, and height and decreased fetal movement. Knowledge related to danger signs during pregnancy is important for pregnant women to know so that they can immediately ask for help when they encounter these danger signs (Napitupulu et al, 2018).

The Maternal and Child Health Book $(\mathrm{MCH})$ also contains important information needed by mothers and families that must be conveyed by health workers through information communication and education to increase knowledge and health behavior of pregnant women and their families so that mothers and families are able to maintain, monitor and improve health. Pregnant women and families must recognize the danger signs as early as possible in pregnancy so that management can be carried out quickly. This can reduce the incidence of high-risk pregnant women and reduce maternal mortality (Kemenkes, 2015).

The Ministry of Health together with the Japan International Coorperation Agency (JICA) has made the MCH book since 1993 until now. It continues to be evaluated and revised periodically according to the needs of mothers and children, along with the times, which contains information on the health of pregnant women, childbirth, postpartum, immunization, growing up. development of toddlers, first handling of sick babies, care of children with disabilities and ways to protect children from sexual violence (Kemenkes, 2015).

The lack of knowledge of mothers about the use of Maternal and Child Health $(\mathrm{MCH})$ books, which is still considered only as a health record book for health workers, becomes an obstacle in shaping the health

*Korespondensi: viantyummukayyisa@gmail.com behavior of pregnant women about the importance of routine pregnancy check-ups, understanding the danger signs of early pregnancy, the importance of taking tablets. Fe regularly, as well as daily health care (Health Department of RI, 2005 in Oktarina, 2015).

The MCH book program is currently one of the priority programs in Indonesia, so that the Government targets the achievement of $\mathrm{MCH}$ book utilization in 2014 which is $85 \%$ (Ministry of Health of RI, 2015). According to Riskesdas data in 2018, the proportion in Indonesia ownership of the MCH Handbook is $65.9 \%, 49.7 \%$ have and can show, $16.2 \%$ have and cannot show (Main Results of Riskesdas, 2018).

The utilization of this MCH handbook is influenced by several factors. Based on the theory developed by Lawrence Green (1991), states that several factors that can influence a person's behavior are the first predisposing factors (knowledge, attitudes, beliefs, values and culture). The low utilization of $\mathrm{MCH}$ books is still constrained by the lack of knowledge and attitudes of mothers about the benefits of $\mathrm{MCH}$ books and some mothers also consider things related to $\mathrm{MCH}$ books as mere examination notes (Yayu, et al, 2015). The second is enabling factors (physical environment, costs, health facilities or facilities). The affordability of distance, the availability of transportation and the availability of health facilities in the mother's environment have a major influence in utilizing health services, one of which is using the MCH handbook (Mulia, 2005). The last is the driving or reinforcing factor (attitude and behavior of health workers) (Notoatmodjo, 2010). The results of research by Hasanbasri and Emoviana (2006) in Sawalunto City showed that $80 \%$ of health workers did not provide counseling to mothers according to the material contained in the $\mathrm{MCH}$ handbook.

Based on the facts, the researcher is interested in conducting research on the relationship between characteristics and mother's perception of the MCH book on Benda Kerep Sub-village, Argasunya Village, Cirebon City. 
This is important to know so that the research results obtained can later provide useful information for the health center, so that the utilization of $\mathrm{MCH}$ books can increase and can also be used in the development of maternal and child health.

\section{METHOD}

This type of research was an observational analytical research with a cross-sectional study design. The population was all pregnant women in Benda Kerep Sub-village, Argasunya Village, Cirebon City. A total of 23 pregnant women were then recruited.

\section{RESULT AND DISCUSSION}

Table 1. Frequency distribution of pregnant women based on perceptions of the $\mathrm{MCH}$ book

\begin{tabular}{ccc}
\hline PERCEPTION & FREQUENCY & \% \\
\hline GOOD & 7 & 30.43 \\
BAD & 16 & 69.56 \\
\hline
\end{tabular}

Based on the distribution table above, the majority of pregnant women haved a bad perception of the $\mathrm{MCH}$ book, which was $69.56 \%$.

Table 2. Frequency distribution of pregnant women by age

\begin{tabular}{ccc}
\hline AGE & FREQUENCY & \% \\
\hline$<\mathbf{2 0}$ & 1 & 4 \\
$\mathbf{2 0 - 3 5}$ & 20 & 87 \\
$>\mathbf{3 5}$ & 2 & 9 \\
\hline
\end{tabular}

Based on the table above, the majority of pregnant women are aged $20-35$ by $87 \%$.

Table 3. Frequency distribution of pregnant women by education

\begin{tabular}{ccc}
\hline EDUCATION & FREQUENCY & \% \\
\hline FINISHING & 18 & 78 \\
ELEMENTARY SCHOOL & & \\
NO EDUCATION & 5 & 22 \\
\hline
\end{tabular}

Based on table 3 above, the majority of pregnant women were in school (graduated from elementary school) by 78 percent.

Table 4. Frequency distribution of pregnant women by gestational age

\begin{tabular}{ccc}
\hline GEST. AGE & FREQUENC & \% \\
& Y & \\
\hline Trimester 1 & 6 & 26 \\
Trimester 2 & 11 & 48 \\
Trimester 3 & 6 & 26 \\
\hline
\end{tabular}

Based on the table above, the majority of pregnant women whose gestational age was included in the second trimester was 14-27 weeks as many as 10 people (48\%).

Table 5. Distribution of the frequency of pregnant women by place of delivery

\begin{tabular}{ccc}
\hline DELIVERY SITE PLAN & $\begin{array}{c}\text { FREQUEN } \\
\text { CY }\end{array}$ & $\%$ \\
\hline Health center & 3 & 13.04 \\
Clinic & 3 & 13.04 \\
Home & 17 & 73.92 \\
\hline
\end{tabular}

Based on table 5, it can be seen that the majority of pregnant women had a plan where the place of delivery was at home by 17 people or $73.92 \%$.

Table 6. Frequency distribution of pregnant women by occupation

\begin{tabular}{ccc}
\hline OCCUPATION & FREQUENC & $\%$ \\
\hline No & 0 & \\
Yes & 23 & 0 \\
\hline
\end{tabular}

Based on table 6, frequency distribution of pregnant women by occupation, all pregnant women did not work 23 people (100\%).

Table 7. Relationship of Maternal Age and Perceptions of MCH Handbooks

\begin{tabular}{|c|c|c|}
\hline PERCEPTION & GOOD & BAD \\
\hline \multicolumn{3}{|l|}{ AGE } \\
\hline$<20$ & 1 & 0 \\
\hline $20-35$ & 7 & 13 \\
\hline$>35$ & 0 & 2 \\
\hline
\end{tabular}


From table 7, it can be seen that of the 21 respondents who had a bad perception of the $\mathrm{MCH}$ handbook, most were aged 20-35 years. After doing statistical test using chi square, it is obtained that $\mathrm{x}^{2}$ count was 3.361 and $\mathrm{x}^{2}$ table with $\mathrm{df}=2$ and $=0.05$, which was 5.991 . Because $x^{2}$ count $<x^{2}$ table, Ha was rejected, meaning that there was no relationship between the age of pregnant women and the mother's perception of the MCH handbook.

Table 8. Relationship of Mother's Education with Perception of MCH Handbook

\begin{tabular}{ccc}
\hline PERCEPTION & GOOD & BAD \\
EDUCATION & & \\
\hline YES & 7 & \\
\hline NO & 1 & 11 \\
\hline
\end{tabular}

From table 8 , it can be seen that of the 23 respondents who had a bad perception of the MCH handbook, most had elementary school education. After the statistical test using chi square, it was obtained $x^{2}$ count of 0.611 and $\mathrm{x}^{2}$ table with $\mathrm{df}=1$ and $=0.05$, which was 3.841. Because $x^{2}$ count $<x^{2}$ table, Ha was rejected, meaning that there was no relationship between the education of pregnant women and the mother's perception of the $\mathrm{MCH}$ handbook.

Table.9 Relationship between Mother's Work and Perceptions of the $\mathrm{MCH}$ handbook

\begin{tabular}{ccc}
\hline PERCEPTION & GOOD & BAD \\
OCCUPATION & & \\
\hline YES & & \\
NO & 0 & 0 \\
\hline
\end{tabular}

From table 9, it can be seen that of the 23 respondents who had a bad perception of the MCH handbook, most did not work. After statistical test using chi square, it was obtained $\mathrm{x}^{2}$ count of 0.211 and $\mathrm{x}^{2}$ table with $\mathrm{df}=1$ and $=0.05$ which was 3.841 . Because $\mathrm{x}^{2}$ count $<$ $\mathrm{x} 2$ table, Ha was rejected, meaning that there was no relationship between the work of pregnant women and the mother's perception of the MCH handbook.
Table 10. The Relationship of Planned Delivery Place with Perceptions of the MCH handbook

\begin{tabular}{lcc}
\hline PERCEPTION & GOOD & BAD \\
PLANNED & & \\
DELIVERY SITE & & \\
\hline HEALTH CENTER & 1 & 2 \\
\multicolumn{1}{c}{ CLINIC } & 2 & 1 \\
\multicolumn{1}{c}{ HOME } & 5 & 12 \\
\hline
\end{tabular}

From table 10, it can be seen that of 23 respondents who haD a bad perception of the MCH handbook, most of them planned to give birth at home. After performing statistical tests using chi square, it wais obtained that $\mathrm{x}^{2}$ count was 1.96 and $\mathrm{x}^{2}$ table with $\mathrm{df}=2$ and $=0.05$, which was 5.991. Because $\mathrm{x}^{2}$ count $<\mathrm{x}^{2}$ table, Ha was rejected, meaning that there was no relationship between planning for a pregnant woman's place of delivery and the mother's perception of the MCH book.

\section{DISCUSSION}

1. Based on the distribution results in table 1, the majority of pregnant women have a bad perception of the $\mathrm{MCH}$ book, which is $69.56 \%$.

Based on the theory by Walgito (2017) perception is a process of receiving a stimulus by an individual through a tool or also called a sensory process. The stimulus will be continued and the next process is the perception process. Among the factors that influence it is age (Nursalam, 2001). The more age, maturity and strength a person will be more mature in thinking and working. Education (Notoatmojo, 2017) Someone with a high education will give a more rational response. Work (Notoatmojo, 2013) someone who works can gain good knowledge about something so that he can perceive something positively.

2. Based on table 2 above, the majority of pregnant women are aged $20-35$ by $87 \%$. And from table 7, it can be seen that of the 21 respondents who have a bad perception of the MCH handbook, most are aged 20-35 years. After doing statistical test using chi square, it is obtained that $\mathrm{x}^{2}$ count is 3.361 
and $\mathrm{x}^{2}$ table with $\mathrm{df}=2$ and $=0.05$, which is 5.991. Because $x^{2}$ count $<x^{2}$ table, Ha is rejected, meaning that there is no relationship between the age of pregnant women and the mother's perception of the $\mathrm{MCH}$ handbook.

From the results of the research above, it is not in accordance with the theory which states that productive age (20-35 years) have good thoughts and understanding regarding their reproductive health, productive age will provide a readier physical condition compared to those aged $<20$ years and $>35$ years.

3. Based on table 3 above, the majority of pregnant women are in school (graduated from elementary school) by 78 percent. And From table 8, it can be seen that out of 23 respondents have a bad perception of the MCH handbook, most have elementary school education. After the statistical test using chi square obtained $\mathrm{x}^{2}$ count of 0.611 and $\mathrm{x}^{2}$ table with $\mathrm{df}=1$ and $=0.05$, which is 3.841 . Because $x^{2}$ count $<x^{2}$ table, $\mathrm{Ha}$ is rejected, meaning that there is no relationship between the education of pregnant women and the mother's perception of the MCH handbook.

According to (Heru, 2005 in Sistiarini 2014) Education is a learning process which means that in education there is a process of growth and development towards individual maturity and maturity. According to (Sukmadinata, 2003 in Sistiarini 2014) Education is needed to obtain information that supports health so that it can improve a person's quality of life.

$\mathrm{MCH}$ book with a very simple and attractive design with various pictures so that it is easy to understand by pregnant women with low education, this means that $\mathrm{MCH}$ book is effective as a medium of communication between pregnant women and health workers. This opinion is in accordance with Nakamura (2010) in Sistiarini (2014) that in Indonesia pregnant women with low education are more interested in using $\mathrm{MCH}$ books compared to pregnant women with higher education.

4. Based on table 4 above, the majority of pregnant women whose gestational age is in the second trimester, namely 14-27 weeks as many as 10 people (48\%). From table 7 , it can be seen that of 21 respondents have a poor perception of the MCH handbook, most are aged 20- 35 years old. After doing statistical test using chi square, it is obtained that $\mathrm{x}^{2}$ count is 3.361 and $\mathrm{x}^{2}$ table with $\mathrm{df}=2$ and $=0.05$, which is 5.991 . Because $x^{2}$ count $<x^{2}$ table, Ha is rejected, meaning that there is no relationship between the age of pregnant women and the mother's perception of the MCH handbook.

The results of Hegiwara's research (2013) that mothers of productive age are more interested in using $\mathrm{MCH}$ books and always carry $\mathrm{MCH}$ books as a medium of communication with health workers. This means that at the age of 20-35, the mother's perception of the MCH book is good, because at the productive age the level of maturity and strength of a person in thinking and acting will be better (Notoatmojo, 2007). However, in this study, pregnant women aged 20-35 years had poor perceptions, this researcher assumed that, there were other factors that could influence this perception, for example education, lack of knowledge due to not working, high interactions between pregnant women and health workers, and other factors not included in the research variables.

5. Based on table 5, it can be seen that the majority of pregnant women have a plan where the delivery place is at home by 17 people or $73.92 \%$. From table 10, it can be seen that of the 23 respondents who have a bad perception of the MCH handbook, most of them plan to give birth at home. After performing statistical tests using chI square, it is obtained that $\mathrm{x}^{2}$ count is 1.96 and $\mathrm{x}^{2}$ table with $\mathrm{df}=2$ and $=0.05$, which is 5.991. Because $x^{2}$ count $<x^{2}$ table, Ha is rejected, meaning that there is no 
relationship between planning for a pregnant woman's place of delivery and the mother's perception of the MCH book.

Birth planning is a standard of service for pregnant women which aims to find out how the psychological fulfillment of maternity is in determining her confidence and comfort for her. One of the planning of delivery is to determine the place of delivery, the selection of the right place of delivery can have an impact on the condition of the mother giving birth. Some research results state that higher education can lead to knowledge about health so that pregnant women can plan to choose a place of delivery in health care facilities.

As research conducted by (Dewi, 2015) that there is a relationship between education and childbirth selection. The results of the study show that the education level of pregnant women in Benda Village is mostly not school gardens, this is assumed to be a factor in choosing childbirth at home.

6. Based on table 6. Frequency distribution of pregnant women by occupation, 23 pregnant women do not work (100\%). From table 9, it can be seen that of the 23 respondents who have a bad perception of the $\mathrm{MCH}$ handbook, most do not work. After statistical test using chi square obtained $\mathrm{x}^{2}$ count of 0.211 and $\mathrm{x}^{2}$ table with $\mathrm{df}=1$ and $=0.05$ which is 3.841 . Because $\mathrm{x}^{2}$ count $<\mathrm{x}^{2}$ table, Ha is rejected, meaning that there is no relationship between the work of pregnant women and the mother's perception of the MCH handbook.

Work can be interpreted as a picture of a family's economic income. In accordance with the theory of perception that work can affect a person in obtaining health knowledge so that it can have an impact on positive thinking.

In this study, all pregnant women have an unemployed status which can be assumed as a lack of insight obtained from external aspects so as to give a bad perception of the $\mathrm{MCH}$ handbook

\section{CONCLUSION}

1. The majority of pregnant women have a poor perception of the $\mathrm{MCH}$ handbook $(69.56 \%)$.

2. The majority of pregnant women are aged 20-35 (87\%).

3. The majority of the education of pregnant women (graduated from elementary school) (78\%).

4. The majority of gestational age is included in the second trimester, namely 14-27 weeks $(48 \%)$.

5. The majority of pregnant women have a plan where delivery is at home (73.92\%).

7. Based on occupation, all pregnant women do not work (100\%).

8. There is no relationship between the age of pregnant women and the mother's perception of the MCH handbook.

9. There is no relationship between the education of pregnant women and the mother's perception of the $\mathrm{MCH}$ handbook.

10. There is no relationship between the work of pregnant women and the mother's perception of the MCH handbook.

11. There is no relationship between the planned place of delivery for pregnant women and the mother's perception of the $\mathrm{MCH}$ handbook.

\section{REFERENCE}

Dewi MAritalia, 2015. Hubungan Pendidikan ibu hamil terhadap Pemilihan Tempat Bersalin Di Wilayah Kerja Puskesmas Peusangan Kabupaten Bireuen. Jurnal Lentera Vol.15 No.14.

Chabib Muhammad .2017. Persepsi Perempuan tentang Penyakit Jantung Koroner Di Puskesmas Jenangan, Kecamatan Jenangan Kabupaten Ponorogo 
Hagiwara, 2013. Is The Maternal and Child Health $(\mathrm{MCH})$ Handbook Effective in Impriving Health - Related Behavior, Evidance From Palestina. Jornal of Public Policy Vol.34,1,31-34.

Kemenkes. 2018. Hasil Utama Riskesdas 2018. Badan Penelitian dan Pengembangan Kemsnkes RI

Notoadmodjo. 2003. Metodologi Penelitian Kesehatan. Jakarta: Rineka Cipta.

Notoadmodjo. 2007.Pendidikan Dan Perilaku Kesehatan. Jakarta: PT Renika Cipta.

Nurhidayat, Saiful, 2011. Asuhan Keperawatan Klien Dengan Gangguan System Kardiovaskuler. Ponorogo. Univeritas Muhammadiyah Ponorogo Press.

Nursalam \& Pariani. 2001. Pendekatan Praktik Metodologi Penelitian Keperawatan. Jakarta: Cv. Agung Setio.

Nursalam. 2003. Konsep Dan Penerapa Metodologi Penelitian Ilm Keperawatan Jakarta: Salemba Medika.

Rahmat, Jalaluddin. 2009. Psikologi Komunikasi. Bandung : remaja rosdakarya

Sistiarni, C (2014). Fungsi Pemanfaatan Buku Kesehatan Ibu dan Anak pada Ibu. Jurnal Kesehatan Masyarakat Nasional, Vol 8 No 8. 